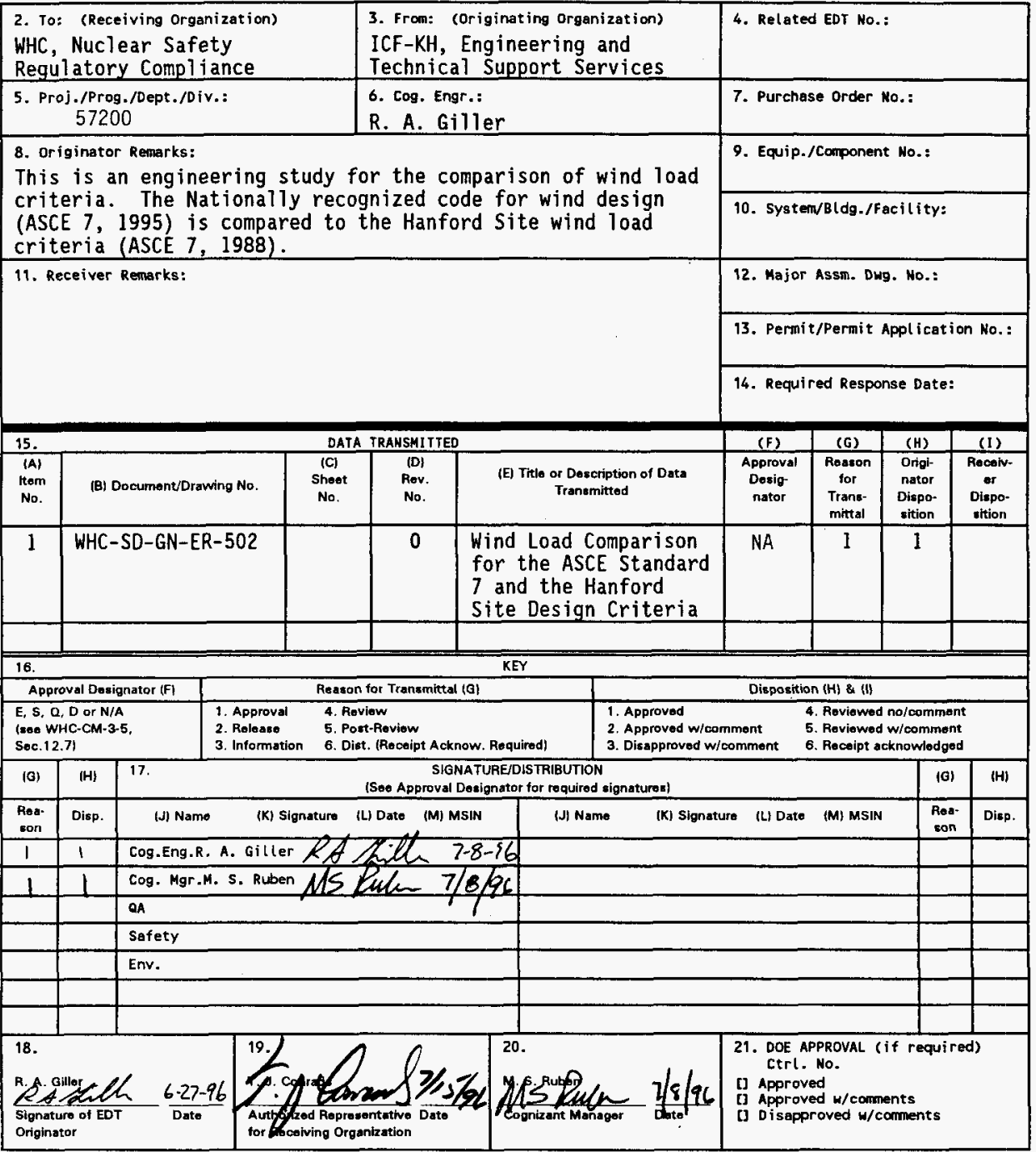




\section{Wind Load Comparison for the ASCE Standard 7 and the Hanford Site Design Criteria.}

R. A. Giller

ICF-KH, Richland, WA 99352

U.S. Department of Energy Contract DE-AC06-87RL10930

EDT/ECN: $\quad 615763$

Org Code: 57200

UC: 2000

B\&R Code: YN100000

Charge Code: E30734

Total Pages: 18

Key Words: Wind Load/Comparison/ASCE 7, 1995/Design Criteria

Abstract: This document provides calculations and discussions to compare Hanford Site wind load criteria with the current national standard for wind loads (ASCE 7, 1995). Site criteria uses the 1988 edition ASCE 7.

TRADEMARK DISCLAIMER. Reference herein to any specific comercial product, process, or service by trade name, trademark, manufacturer, or otherwise, does not necessarily constitute or imoly its endorsement, recommendation, or favoring by the United States Government or any ageney thereof or its contractors or subcontractors.

Printed in the United States of Mnerica. To obtain copies of this document, contact: WHC/BCS Document Control Services, P.0. Box 1970, Mailstop H6-08, Richtand WA 99352, Phone (509) 372-2420; Fax $(509) 376-4989$.
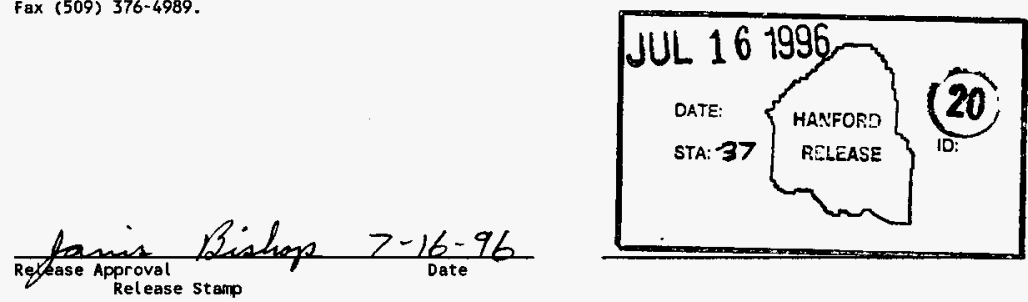

\section{Approved for Public Release}


WIND LOAD COMPARISON

FOR THE ASCE STANDARD 7

AND THE HANFORD SITE DESIGN CRITERIA

Prepared By:

A. A. Avile

Date: $6-27-96$

Richard A. Giller, Senior Engineer

Engineering and Technical Support Services

ICF Kaiser Hanford Company

Reviewed By:

Nguyen D. Ha, Senior Engineer

Date: $6-27-96$

Engineering and Technical Support Services

ICF Kaiser Hanford Company

Reviewed By: $\frac{\text { Michael S. Ruben, Manager Date: } 6 / 28 / 96}{7}$ Engineering and Technical Support Services

ICF Kaiser Hanford Company

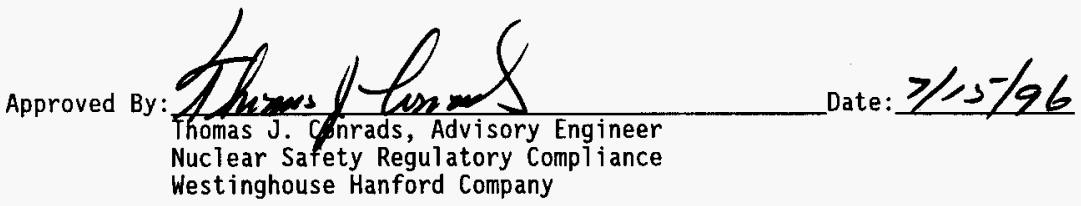

Westinghouse Hanford Company

Hanford 0perations and Engineering Contractor

for the Department of Energy 


\subsection{INTRODUCTION}

The American Society of Civil Engineers standard 7 (ASCE-7) is the nationally recognized standard for wind loads. This standard also contains guidance for snow, rain and seismic loads. This standard was first issued in 1988 and revised in 1993 and 1995 . Current site design criteria reference the 1988 edition of ASCE-7 for the design of wind loads. The abstract to the 1995 revision states that "The major revision of this standard involves the section on wind." An evaluation is needed to determine the impact and extent of the wind load and other load changes made in the 1995 edition.

\subsection{Purpose}

The purpose of this evaluation is to investigate the changes made in the 1995 revision of ASCE-7. Wind, snow and rain loads shall specifically be investigated, seismic loads are not to be a part of this investigation. A determination is needed for the impact these changes will make to site design criteria and if changes to the site design criteria are necessary.

\subsection{Background}

Wind speed data is recorded and archived at National Weather Stations (NWS) around the country. The National Weather Service has phased out the measurement of fastest mile wind speeds in favor of peak gust wind speeds. Along with the change from fastest-mile to peak-gust wind speed, is an adjustment in gust factors such that most regions of the country will not see significantly different wind pressures. Only hurricane susceptible regions of the country have reported larger calculated wind pressures.

Changes to ASCE 7 also include new wind load considerations for structures. Wind produced torsion and biaxial loading on buildings and wind speed increase on buildings located on isolated hills require additional investigation. These additional considerations can be significant.

\subsection{SITE DESIGN CRITERIA}

The following list provides the current site design criteria documents that have sections dealing with wind loads.

GC-LOAD-01, Design Loads for Facilities. March, 1996.

UCRL-15910, Design and Evaluation Guidelines for DOE Facilities

$\begin{array}{ll} & \text { Subjected to Natural Phenomena Hazar } \\ \text { UBC-1994, } & \text { Uniform Building Code. May, } 1994 .\end{array}$

ASCE-7, 1988, Minimum Design Loads for Buildings and other Structures. December, 1988.

WHC-CM-1-12, Structural Design and Evaluation Criteria. Draft May, 1996. DOE-STD-1020, Natural Phenomena Hazards Design and Evaluation Criteria for Department of Energy Facilities. Apri1, 1994. 


\subsection{ASCE STANDARD-7 WIND LOAD COMPARISON}

The 1995 edition of ASCE-7 has major wind load changes and additions from the 1988 edition. These changes and additions in some cases increase and in other cases, decrease the wind loading on a structure. The following sections describe the changes in the 1995 edition of ASCE-7.

\subsection{Wind Velocity Difference}

The annual probability of maximum wind speed remains unchanged at 0.02 in the 1995 edition of ASCE-7. However, the method of reporting that wind speed has changed from a fastest-mile to a three-second-gust wind designation. The basic wind speed map provided in ASCE-7 has also changed. The 1988 map had three different wind speeds (exclusive of the gulf coast and Alaska), the 1995 map has one wind speed for the west coast and one for the rest of the country (exclusive of the gulf coast and Alaska).

\subsection{Basic Velocity Pressure Differences}

The basic formula for calculating velocity pressure is unchanged in the 1995 edition of ASCE-7 (see below). However, some of the values of the terms in the formula have changed. The wind velocity (V) has changed from fastest-mile to three-second-gust, the exposure coefficient (K) has been replaced by two exposure coefficients, and the importance factor (I) is no longer squared with the velocity term as it was in the 1988 edition.

$$
\begin{array}{ll}
\text { (ASCE 7, 1988) } & q_{z}=0.00256 K_{z}(I V)^{2} \\
\text { (ASCE 7, 1995) } & q_{z}=0.00256 K_{z} K_{z} V^{2} I
\end{array}
$$

\subsection{Design Wind Pressure Differences}

The design wind pressure used in the evaluation of structures for wind loads is calculated from the basic velocity pressure. Wind pressure coefficients that vary by the building component under consideration are used to modify this pressure. Because of the many factors, coefficients, and variables that go into the calculation of the design wind pressure, it is impossible to determine the differences unless case studies are performed.

Five case studies were performed to calculate design wind pressures on buildings, cladding, and components for the 1988 and 1995 editions of ASCE-7. These case studies are provided in Appendix B. Table 1 shows the design wind pressure results for three of these studies, the two remaining case studies showed no changes. Table 1 shows some design wind pressure differences for low-rise building main load-resisting frame. 
Table 1.

Case Study

Design Pressure Results

\begin{tabular}{|l|c|c|l|l|}
\hline \multicolumn{2}{|c|}{ Load Case } & $\begin{array}{l}\text { Main Load- } \\
\text { Resisting } \\
\text { Frame }\end{array}$ & $\begin{array}{l}\text { Maximum Roof } \\
\text { Component or } \\
\text { Cladding } \\
\text { Pressure }\end{array}$ & $\begin{array}{l}\text { Maximum Wal1 } \\
\text { Component or } \\
\text { Cladding } \\
\text { Pressure }\end{array}$ \\
\hline $\begin{array}{l}\text { CASE 1 } \\
\text { Flat Roof, } \\
\text { Low Rise Bldg } \\
\text { H=50' }\end{array}$ & ASCE-1988 & 22.3 psf & 60.4 psf & 32.0 psf \\
\cline { 2 - 5 } & ASCE-1995 & 13.9 psf & 60.2 psf & 31.9 psf \\
\hline $\begin{array}{l}\text { CASE 2 } \\
\text { Sloped Roof } \\
\text { Low Rise Bidg } \\
\text { h=50' }\end{array}$ & ASCE-1988 & 22.3 psf & 46.1 psf & 32.0 psf \\
\cline { 2 - 5 } $\begin{array}{l}\text { CASE 3 } \\
\text { High Rise } \\
\text { h=80' }\end{array}$ & ASCE-1995 & 19.4 psf & 46.1 psf & 31.9 psf \\
\cline { 2 - 5 } & ASCE-1995 & 24.8 psf & 75.7 psf & 44.4 psf \\
\hline
\end{tabular}

Table 2.

Classification and Importance factors

for Buildings and Other Structures

\begin{tabular}{|c|c|c|c|c|}
\hline Classification of Buildings & $\begin{array}{c}\text { Category } \\
1988\end{array}$ & $\stackrel{1}{1988}$ & $\begin{array}{c}\text { Category } \\
1995\end{array}$ & $\underset{1995}{I}$ \\
\hline $\begin{array}{l}\text { Buildings and other structures } \\
\text { that represent a low hazard to } \\
\text { human life in the event of } \\
\text { failure. }\end{array}$ & IV & 0.95 & I & 0.87 \\
\hline $\begin{array}{l}\text { All buildings and other } \\
\text { structures except those listed in } \\
\text { the other categories. }\end{array}$ & I & 1.0 & II & 1.0 \\
\hline $\begin{array}{l}\text { Buildings and other structures } \\
\text { that represent a substantial } \\
\text { hazard to human life in the event } \\
\text { of failure. }\end{array}$ & II & 1.07 & III & 1.15 \\
\hline $\begin{array}{l}\text { Buildings and other structures } \\
\text { designated as essential } \\
\text { facilities. }\end{array}$ & II I & 1.07 & IV & 1.15 \\
\hline
\end{tabular}




\subsection{Importance Factor}

Building classification definitions and category numbers have been revised to make them more logical. The importance factors (I) have been changed to reflect this logic and have been adjusted and included in the wind velocity formula (Page 2) to the first power. Table 2 provides a comparison for the building classification definitions, category and the corresponding I values. With the exception of Category IV (1988) buildings, the net result of the importance factor revisions is no effect. In the above exception the 1988 Category IV calculation would be conservative.

\subsection{Additional Wind Load Considerations}

The 1995 edition of ASCE-7 includes three new wind load design considerations. These new considerations consist of wind speed-up and pressure increase at the crest of hills or escarpments, building torsion produced by wind at building corners, and biaxial wind loading. Specific methods have been included in ASCE-7 1995 to calculate these additional wind pressures and 1oads, and to apply them to building structures.

\subsection{ASCE STD-7 OTHER LOADS COMPARISON}

\subsection{Seismic Load Comparison}

The section on seismic loads had major revisions in the 1993 edition of ASCE-7. However, the Hanford Site does not use the ASCE-7 seismic load provisions and further discussion is not needed here.

\subsection{Snow Load Comparison}

The basic equation for calculating snow loads on roofs has not been changed from 1988 to 1995. However, the values of one coefficient in the equation have changed. The roof exposure coefficient $C_{e}$ has been changed to add more choices and definitions. Previously there were 5 choices ranging from 0.8 to 1.2 , now there are 15 choices ranging from 0.7 to 1.3 .

One other change in the snow load criteria is the ground snow load map. The new map has better definition because county lines are shown for each state. The ground snow load magnitudes are slightly changed through out the country but are unchanged for the Hanford site.

\subsection{Rain Load Comparison}

The 1995 edition of ASCE-7 provides an equation to calculate rain loads on roofs that have drain systems. The 1995 edition also requires a rain load structural analysis for roofs with slopes less than $1 / 4 \mathrm{in} . / \mathrm{ft}$. Both of these requirements are new in the 1995 edition of ASCE-7. 


\subsection{CONCLUSIONS AND RECOMMENDATIONS}

\subsection{Wind Load Results}

The most visible revision in the ASCE-7 1995 document is the change of wind speed reporting designation from fastest-mile to three-second-gust winds. However, this change in wind speed reporting designation has minor overall wind load effects. Some revisions in the ASCE-7 1995 document do have significant effects, for example the wind load effects on the main loadresisting frames of low rise buildings is reduced from the 1988 document. Additionally, the revised ASCE-7 1995 document provides increased wind load effects for torsion, biaxial loading and pressure at hill crests.

Table 1 summarizes the results from three case studies for the calculation design wind pressures. Following is an itemization of the wind load changes from 1988 to 1995 .

- Main Frame design wind pressures have been reduced for low rise buildings, and flat roofed low rise buildings have been reduced more than sloped roofed low rise buildings.

- Increased design wind pressures are required for buildings at the crest of hills or escarpments where wind can speed up.

- Wind hitting a building corner causes torsion in buildings, and a method is provided in the 1995 edition to calculated this effect.

- The effects of biaxial wind loading is a new requirement in the 1995 edition.

- Three new roof types and one new building type has been added to ASCE-7. Monoslope, stepped, and sawtooth roof types, and a partially-open building type are now available for use by design professionals.

The site design criteria listed in Section 2.0 of this document all have wind load design information that will require changing when the 1995 edition of ASCE-7 is adopted. This includes a wind reporting designation change from fastest-mile wind to three-second-gust and an importance factor change. Appendix A provides a recommended wind load criteria table for use in these existing criteria documents.

\subsection{Snow Load Results}

The 1995 edition of ASCE-7 has new values for the snow load coefficients and a new ground snow load map. The change to the Hanford Site is minor and no change is required to the site design criteria.

\subsection{Rain Load Results}

The 1995 edition of ASCE-7 has new requirements for rain loads. Roofs with drainage systems and roofs with slopes less than $1 / 4 \mathrm{in./ft}$ require analysis. The Hanford Site design criteria will need to include this when ASCE-7 1995 is adopted. 
Table $1 A$.

Wind Load and Missile Criteria

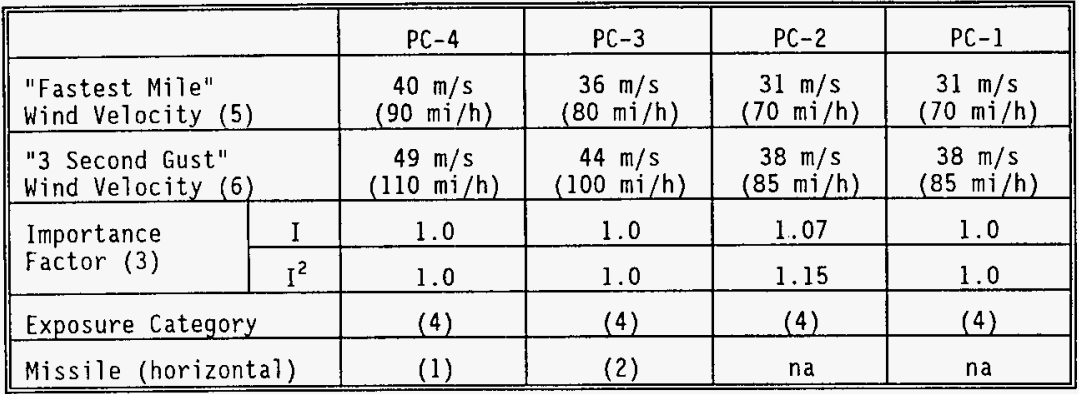

(1) $50 \times 100 \mathrm{~mm}(2 \times 4)$ timber plank weighing $7 \mathrm{~kg}(151 \mathrm{~b})$ ? $22 \mathrm{~m} / \mathrm{s}(50 \mathrm{mi} / \mathrm{h})$. maximum trajectory height $=15 \mathrm{~m}(50 \mathrm{ft}$.

(2) $50 \times 100 \mathrm{~mm}(2 \times 4)$ timber plank weighing $7 \mathrm{~kg}(15 \mathrm{lb})$ ? $22 \mathrm{~m} / \mathrm{s}(50 \mathrm{mi} / \mathrm{h})$. maximum trajectory height $=9 \mathrm{~m}(30 \mathrm{ft}$.)

(3) Wind pressures calculated in accordance with ASCE 7, 1988 vary according to the square of the "I" term $\left(I^{2}\right)$. The UBC and ASCE 7, 1995 Importance Factors for wind corresponds to $\mathrm{I}^{2}$ from ASCE 7, 1988.

(4) Exposure " $\mathrm{C}$ ", flat and generally open terrain, should be used for all construction unless it can be shown that the necessary permanent shielding will be provided by natural terrain (not including shielding from trees or adjacent buildings).

(5) See WHC-SD-GN-ER-501.

(6) ASCE 7, 1995 uses a Three Second Gust wind velocity in place of the Fastest Mile wind velocity.

The wind pressure increase due to nearby terrain features, building torsion produced by wind and biaxial wind loading of buildings are effects that must be structurally investigated as described in ASCE 7, 1995. 




Wind Load Comparison for the ASCE Standard \& and the Hanford Site Design Criteria

Purpose:

Compare the ASCE-7 1988 and 1995 editions of this standard. Evaluate the effects and impact that these changes will have to the Hanford Site Design Criteria.

Scope:

This evaluation and comparison will investigate the changes in ASCE-7 for wind, snow, and other loads except seismic. The results shall be reported in an SD document.

Site Design Criteria:

GC-LOAD-01, Design Loads for Facilities.

UCRL-15910, Design and Evaluation Guidelines for DOE Facilities Subjected to Natural Phenomena Hazards.

UBC-1994, Uniform Building Code.

ASCE-7, 1988, Minimum Design Loads for Buildings and Other structures.

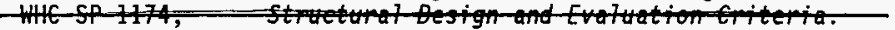

WHC-CM-1-12, Structural Design and Evaluation Criteria.

DOE-STD-1020, Natural Phenomena Hazards Design and Evaluation Criteria for DOE Facilities.

Conclusions:

The wind designation change from fastest mile to 3 second gust winds does not change the wind loads at the Hanford Site. The wind speed contours map change a) so does not change the wind loads at Hanford. There are three significant changes in ASCE-7 1995 that do change wind loads at Hanford and they are listed as follows.

1. Low rise buildings have lower wind loading in ASCE-7, 1995.

2. All buildings must now be evaluated for torsion wind effects.

3. Wind loads in biaxial directions must now be combined.

Snow, and Kain loads have some sma 11 changes as discussed in the report. Most of the above site design criteria documents give wind load information based on the ASCE-7, 1988 which will require changing to match the 1995 edition. 
KAISER ENGINEERS

DESIGN ANALYSIS
WHL-SD-GN-ER- 502 ReV. O

Talc. No.

Revision

Page No. 23 of

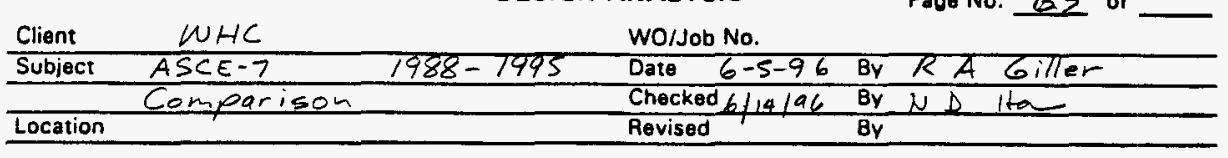

CASE $1: h=50^{\circ}, \theta<10^{\circ}$

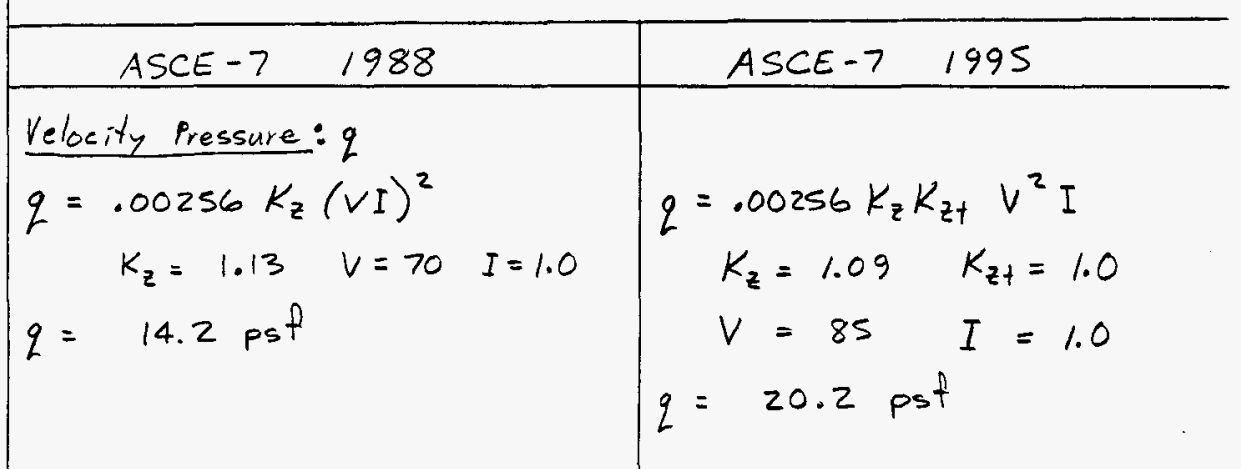

Design Wind Pressures: $P$

Main Frame

$$
\begin{aligned}
P & =q G_{h} C_{p}-q G_{Q} C_{P} \quad \begin{array}{c}
\text { windward } \\
\text { leeward }
\end{array} \\
& =q(1.21)(.8)-q(.25) \quad \begin{array}{l}
\text { windward } \\
\text { wall }
\end{array} \\
& +q(1.21)(.5)+q(.25) \quad \begin{array}{l}
\text { lee ward } \\
\text { wall }
\end{array} \\
P & =q(1.21)(.8+.5)=22.3 \text { psf }
\end{aligned}
$$

Cladding \& Components

$$
P=q\left[G C_{p} \pm G C_{p_{i}}\right]
$$

Main Frame

$$
\begin{aligned}
P & =q\left[G C_{P f}-G C_{p}\right] \\
& =q[.4-.18] \quad \text { windward } \\
& +q[.29+.18] \quad \text { leeward } \\
p & =q(.4+.29)=13.9 \text { psf }
\end{aligned}
$$

Cladding \& Components

$$
P=q\left[G C_{p}-G C_{p_{i}}\right]
$$

54-4300-037 KEH-0037.00 (06/92) 


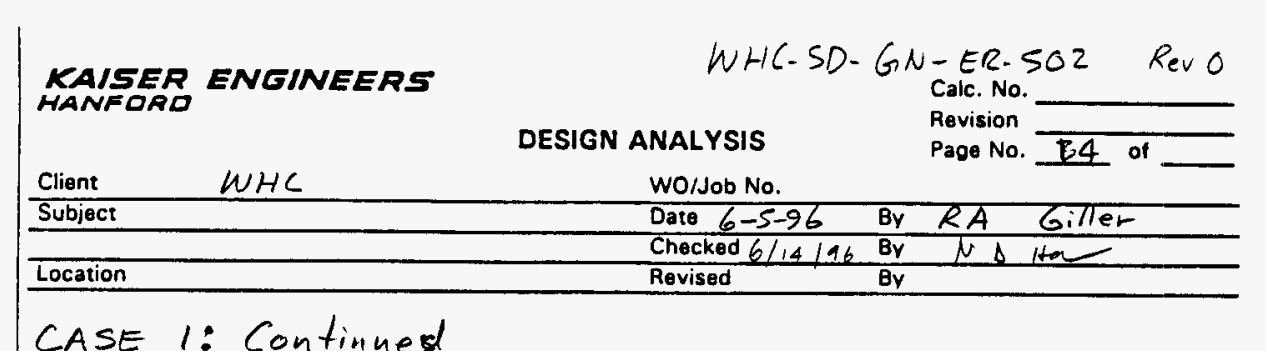

CASE 1: Continued

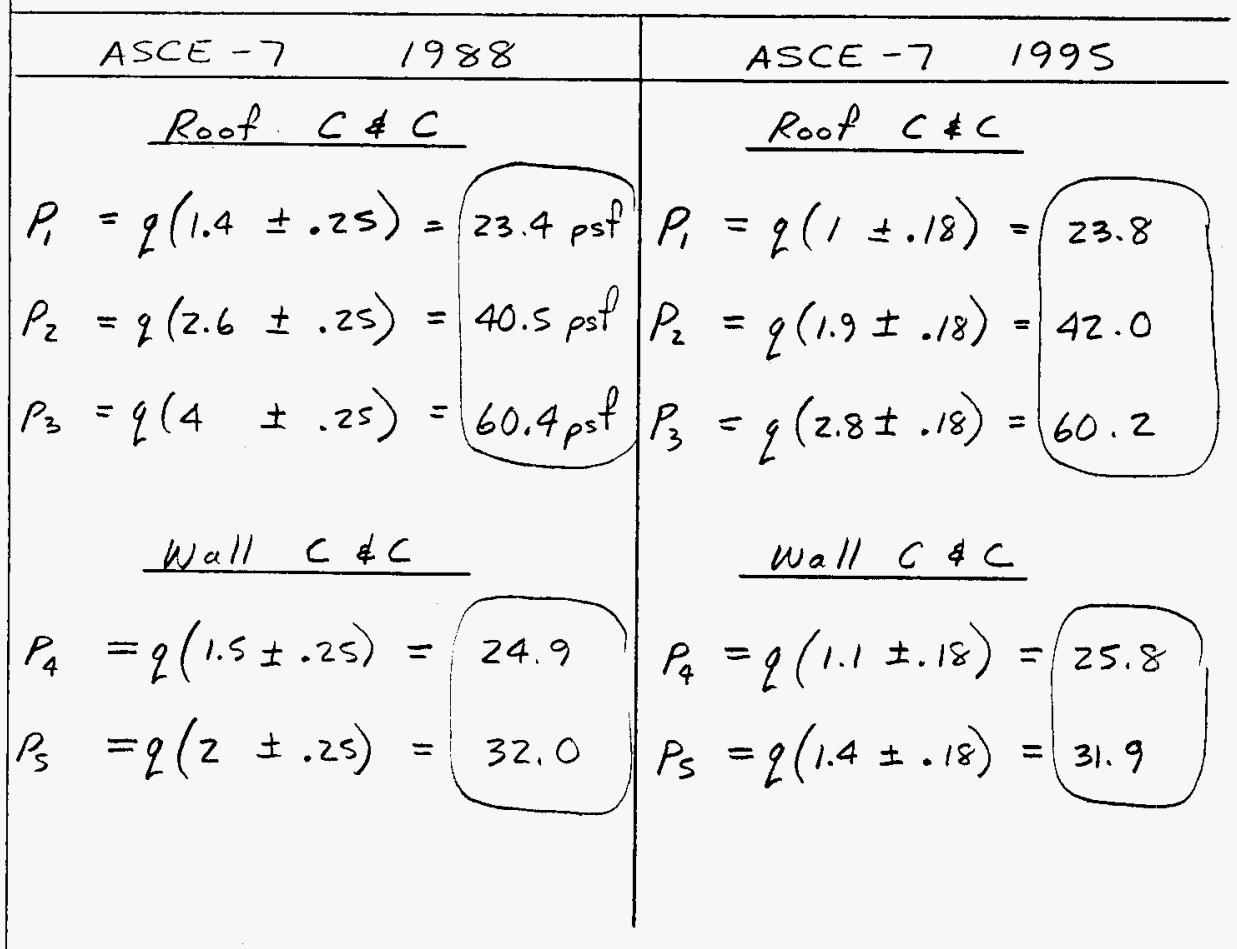

54.4300-037 KEH-0037.00 108/921 


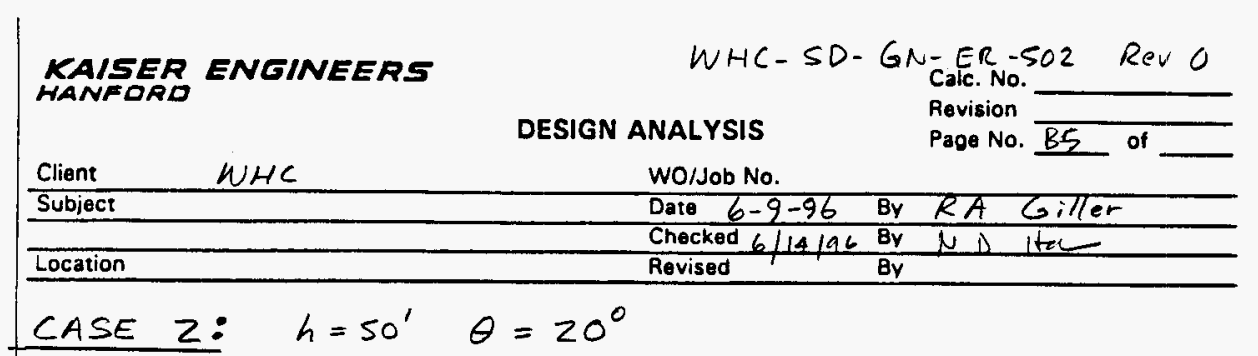

CASE Z: $h=50^{\prime} \quad \theta=20^{\circ}$

\begin{tabular}{|c|c}
\hline ASCI $-7 \quad 1988$ & ASCI -71995 \\
\hline Velocity Pressure: & $q=20.2$ psf
\end{tabular}

Design Pressure:

$$
P=\frac{\text { Main Frame }}{22.3 \text { pst }}
$$

Roof $C \notin C$

$$
\begin{aligned}
& P_{1}=q(1.3+.25)=22.0 \\
& p_{2}=q(3+.25)=46.1 \\
& p_{3}=q(3+.25)=46.1
\end{aligned}
$$

Wall $c \notin C$

$$
\begin{aligned}
& P_{4}=q(1.5 \pm .25)=24.9 \\
& P_{5}=q(2 \pm .25)=32.0
\end{aligned}
$$

Main Frame

$$
P=q(.53+.43)=19.4 \text { psf }
$$

Roof $C \& C$

$$
\begin{aligned}
& P_{1}=q(.9+.18)=21.8 \\
& P_{2}=q(2.1+.18)=46.1 \\
& P_{3}=q(2.1+.18)=46.1
\end{aligned}
$$

wall c\&c

$$
\begin{aligned}
& P_{4}=q(1.1+.18)=25.8 \\
& P_{5}=q(1.4+.18)=31.9
\end{aligned}
$$

54.4300-037 KEH-0037.00 106/92) 


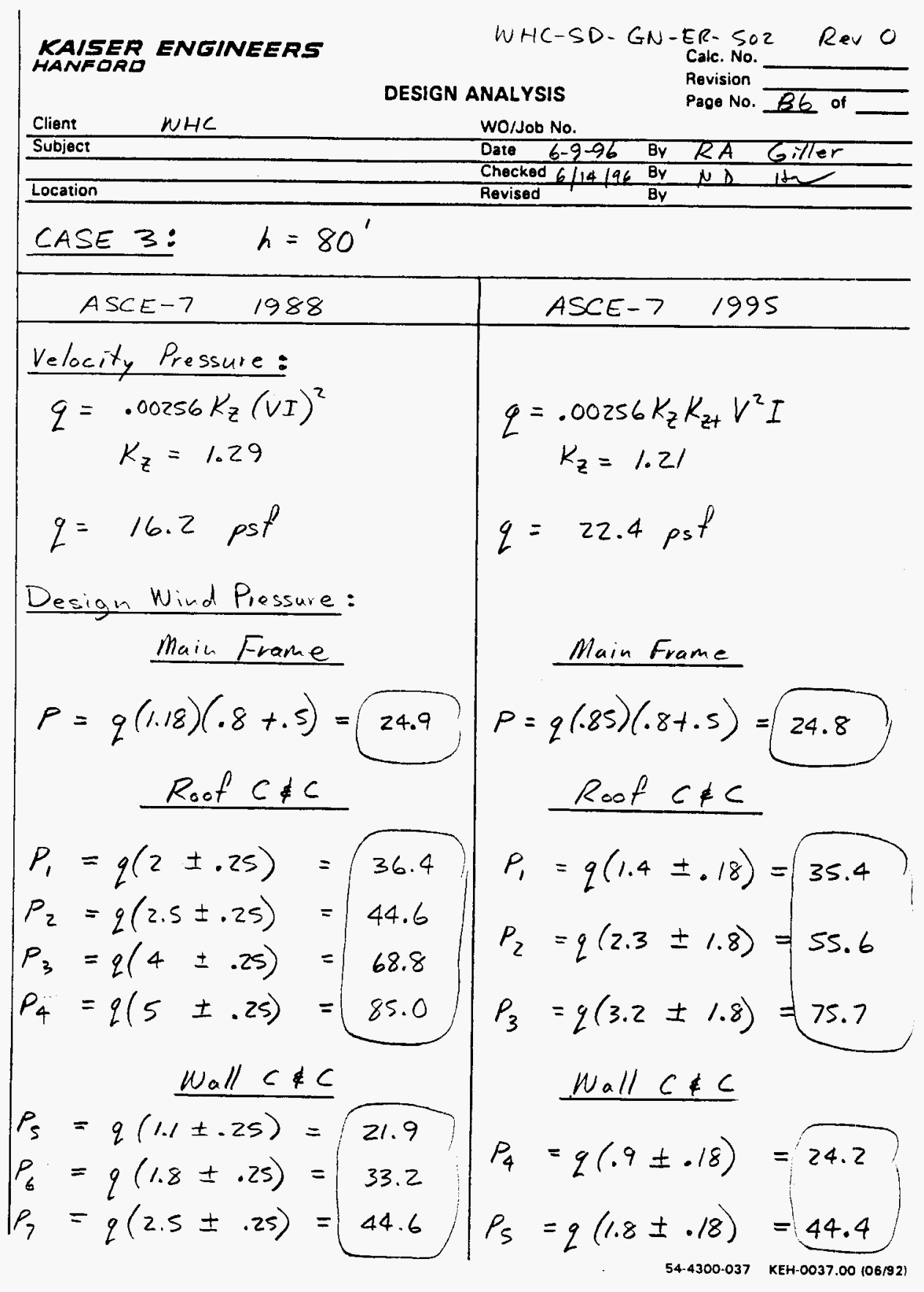


KAISER ENGINEERS

Client WHC

$$
\text { WHC.SD-GN-ER- } 502 \text { ReV } 0
$$

Cali. No.

Revision

Page No. $B 7$ of
DESIGN ANALYSIS

$$
\text { WO/Jab No. }
$$$$
\text { Date 6-5-96 By RA billed }
$$

Checked $6 / 14 / 196$

Revised

Location

CASE 4: flexible Bldg, $h=80^{\circ}$

\begin{tabular}{c|c}
\hline ASCE-7 1988 & ASCE-7 1995 \\
\hline Velocity Pressure: & $q=22.4$ psf $\begin{array}{c}\text { same as } \\
\text { case 3 }\end{array}$ \\
$q=16.2$ pst same as \\
$\begin{array}{c}\text { Case 3 } \\
\text { case }\end{array}$
\end{tabular}

Design Wind Pressure:

$$
\begin{gathered}
p=q \bar{G} \frac{\text { Main Frame }}{C_{p}} \\
p=q \bar{G}(.8+.5)=1.3 q \bar{G} \\
\bar{G}=G_{f}=\begin{array}{r}
\text { responses obtained } \\
\text { by rational } \\
\text { analysis }
\end{array} \\
\text { Roof } \notin \text { Wall } C \notin C
\end{gathered}
$$

same as case 3

$$
\begin{aligned}
& p= \frac{\text { Main Frame }}{q G_{f} C_{p}} \\
& p= q G_{f}(.8+.5)=1.3 q G_{f} \\
& G_{f}=\bar{G}= \text { response obtained } \\
& \text { by rational analysis }
\end{aligned}
$$

Roof $\notin$ Wall $C \notin C$

same as case 3

54-4300-037 KEH-0037.00 106/92 


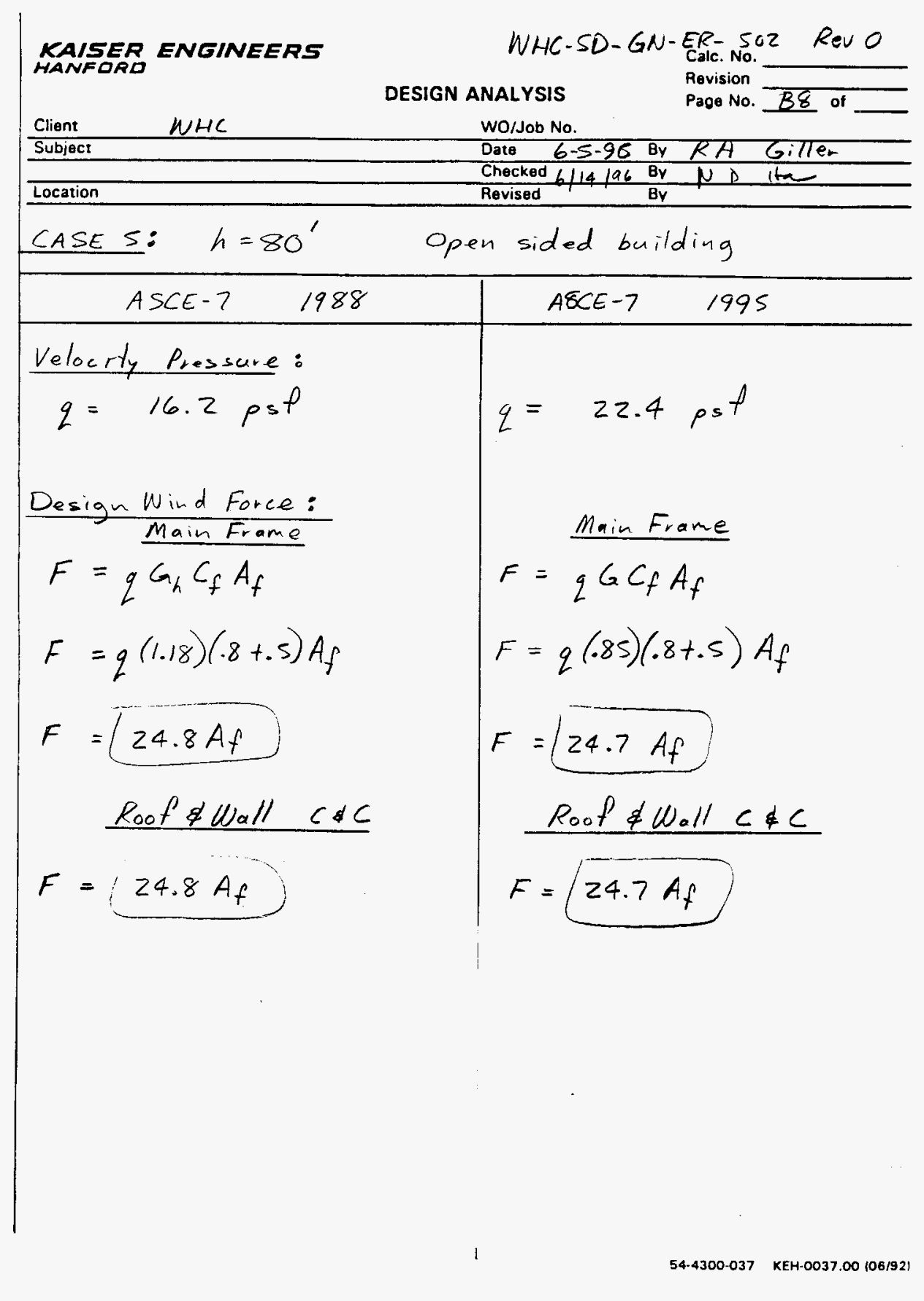


KAISER ENGINEERS

HANFORD

Client

WHO

Subject

Location
WHC-SD-GN-ER-SO2 ROO

Cali. No.

Revision

DESIGN ANALYSIS

Page No. BY of

Wo/Job No.

Date 6-5-96 By RA Gilled

Checked $6 / 14 / 96$ By $N \Delta$ ta

Torsion Effects:

Low Rise Building

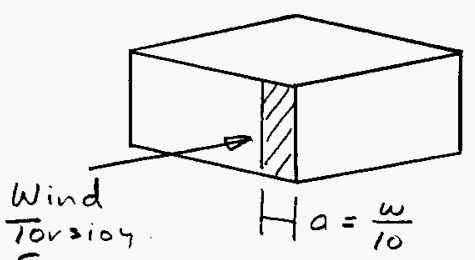

Fore e

$T$

Example
Assume:

Shear wall structure lateral wind force

$$
F=100^{k}
$$

so k each wall

Torsion force

$$
\begin{aligned}
T & =100\left(\frac{1}{10}\right)\left(\frac{.61-.4}{.4}\right) \\
& =5.25^{\mathrm{K}}
\end{aligned}
$$

Find wind force

$$
\begin{aligned}
50+5.25 & =55.25 \mathrm{k} / \text { wall } \\
\frac{5.25}{50} & =10 \% \text { increase }
\end{aligned}
$$

54.4300-037 KEH-0037.00 (06/92) 


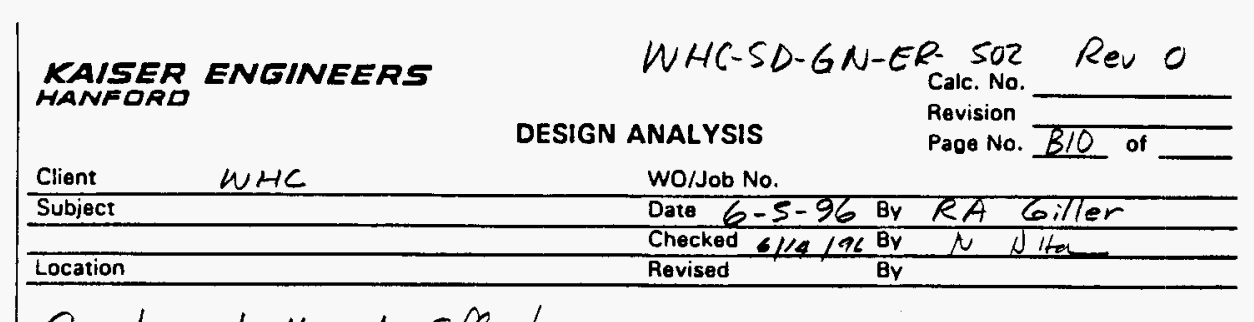

Combined Wind Effects:

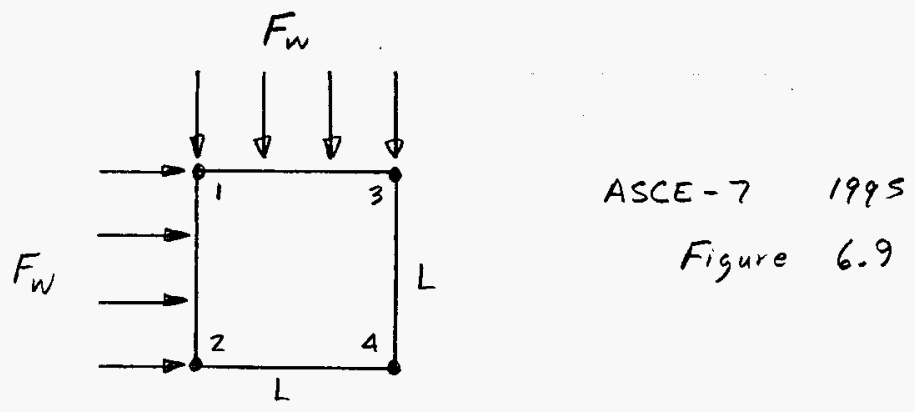

$\left[\begin{array}{l}\text { Find load in each column for } \\ \text { a wind force in one direction only. }\end{array}\right]$

Col. $1,2,3,4= \pm\left(F_{w}\right)\left(\frac{h}{2}\right) \div L(2$ columns $)=\frac{F_{w} h}{4 L}$

$\left[\begin{array}{l}\text { Find load in columns for } 75 \% \\ \text { wind force in each direction }\end{array}\right]$

$.25 F_{w} h / L$

$$
\begin{aligned}
& \text { Col. } 1-4= \pm\left(\frac{3}{4} F_{w}\right)\left(\frac{h}{2}\right) \div 2 L \pm\left(\frac{3}{4} F_{w}\right)\left(\frac{h}{2}\right) \div 2 L \\
& 1= \pm \frac{3 F w h}{16 L} \pm \frac{3 F w h}{16 L} \\
& = \pm \frac{6 F_{w h}}{16 L} \text { or } 0
\end{aligned}
$$$$
= \pm .375 \mathrm{Fwh} / \mathrm{L} \Rightarrow \text { are } 50 \% \text { higher }
$$

loaded

54-4300-037 KEH-0037.00 (06/92) 


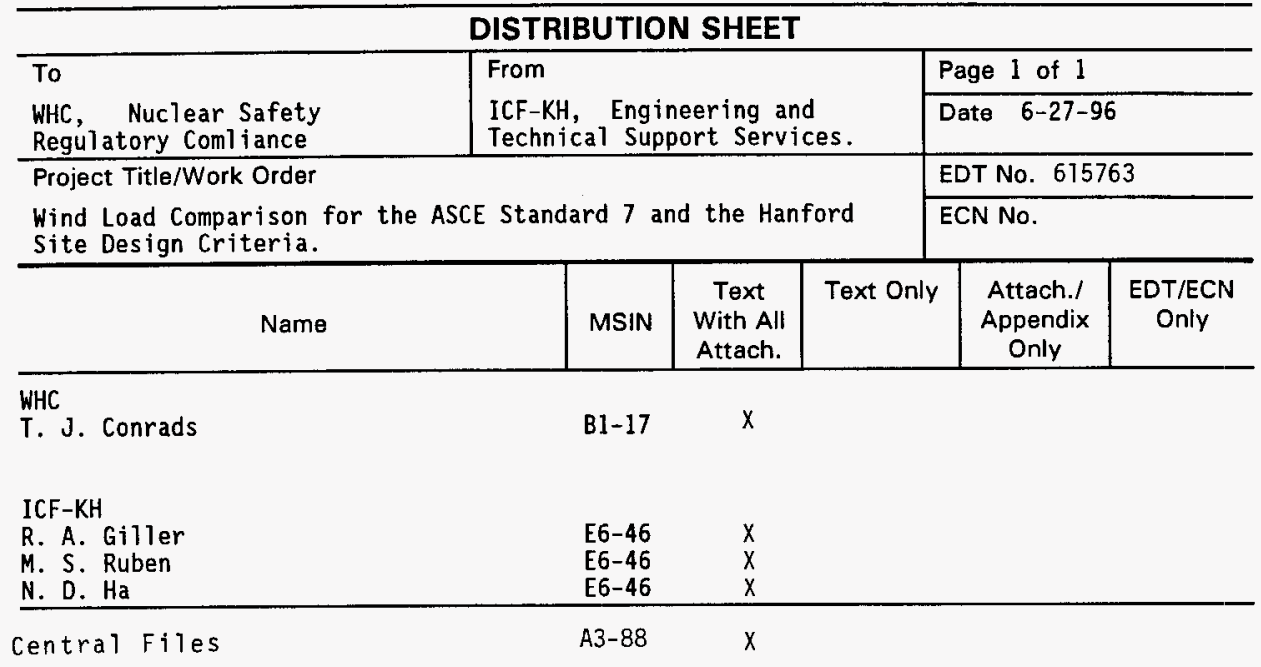

